\title{
Influence of Water Content on the Quality of Pigeonpea Seeds
}

\author{
Cristiane Fernandes Lisboa', Rodrigo Starnek Lopes De Araújo1, Itamar Rosa Teixeira ${ }^{1 *}$, \\ José Hortêncio Mota², Alessandro Guerra Da Silva ${ }^{3}$, Marcos Eduardo Viana De Araújo', \\ Deyner Damas Aguiar Silva1, Edgar Estevam França1, Isneider Luiz Silva1, \\ Fernando Ribeiro Teles De Camargo ${ }^{1}$
}

\author{
${ }^{1}$ Department of Agricultural Engineering, Sate University of Goiás, Anápolís, Brazil \\ ${ }^{2}$ Department of Agricultural, University of Rio Verde, Rio Verde, Brazil \\ ${ }^{3}$ Department of Agricultural, Federal University of Goiás, Jataí, Brazil \\ Email: *itamar.texeira@ueg.br
}

How to cite this paper: Lisboa, C.F., De Araújo, R.S.L., Teixeira, I.R., Mota, J.H., Da Silva, A.G., De Araújo, M.E.V., Silva, D.D.A., França, E.E., Silva, I.L. and De Camargo, F.R.T. (2017) Influence of Water Content on the Quality of Pigeonpea Seeds. American Journal of Plant Sciences, 8, 2397-2406. https://doi.org/10.4236/ajps.2017.810162

Received: August 7, 2017

Accepted: September 10, 2017

Published: September 13, 2017

Copyright $\odot 2017$ by authors and Scientific Research Publishing Inc. This work is licensed under the Creative Commons Attribution International License (CC BY 4.0).

http://creativecommons.org/licenses/by/4.0/

\begin{abstract}
The species Cajanus cajan L. where pigeonpea is from presents a harvest potential in tropical regions for it is used as human and animal feed, besides being used as green fertilizer. However, the harvest area of this Fabaceae is still insignificant, due to especially the lack of quality seeds. In this context, it is possible to affirm that drying and store are portrayed as important steps for obtaining superior quality seeds. The aim of this study is to evaluate the physiologic quality of dwarf pigeonpea seeds, with different water content during storage. A factorial scheme $3 \times 6$ was adopted in the delimitation completely randomized, with four replications. Treatments were constituted by the combination of lots of seeds containing three different water contents (11\%, 14\% and $16 \%$ ), submitted to a 10 -month storage period, with evaluations every two months $(0,2,4,6,8$ and 10). Seeds were stocked in a bag type kraft under normal lab conditions, that is, no control. Physiologic quality of the seeds was evaluated through the following tests: Germination Pattern Test-GPT, first count of germination, accelerated aging and electric conductivity. It can be concluded that pigeonpea with hard seeds containing water content at $11 \%$ existing superior physiologic quality throughout the 10-month storage, under no controlled condition, certainly promoted by the less intense breathing from the reserves cumulated in the seed lot. Pigeonpea seeds storage with water content superior to $14 \%$ promotes a sharp decrease of physiologic quality, due to an increase in metabolic activity.
\end{abstract}

\section{Keywords}

Cajanus cajan L., Physiologic Deterioration, Seed Quality, Viability and Vigour 


\section{Introduction}

Pigeonpea (Cajanus cajan) is a plant from the Fabaceae family and from tropical weather, with its origin still under discussion, once there are ancient reports in Asia and Africa. This crop can be found in the tropics and the semi-arid tropics region of the world, but mainly in Asia, Africa, Latin America and the Caribbean [1], due to its easy adaptation to several soil and weather conditions. Its seeds have high protein content, $21 \%$ and $25 \%$, and are mainly used for human consumption as dry split peas (dal), or as immature green peas (fresh or canned) [2].

The crop has a number of additional roles in subsistence agriculture: after harvesting, the plants are used as fuel and construction materials; most leaves drop to the ground during the crop growth period and add organic matter to the soil; the roots have rhizobia that fix nitrogen (up to $40 \mathrm{~kg} \cdot \mathrm{ha}^{-1}$ ) and help to release bound phosphorus in the soil; grain and leaves are used as feed and fodder; and leaves and roots have medicinal properties [3]. For it is a plant that is adapted to a drier weather, associated with a low nutritional demand, pigeonpea can be a good alternative for crops in the "Cerrado", Brazil, especially for interim-harvest, where it would be used in rotation/succession scheme, aiming the furnishing of $\mathrm{N}$ via green fertilization.

Despite the great potential, pigeonpea crop did not have its area expanded in Brazil due to some points, such as: little enhanced genetic material available to farmers, no-existence of productive and tolerant plague and diseases cultivars, lack of sensible harvest systems with return warranty to producer from the amount of money invested in the activity, low offer of good quality seeds in the market. Regarding the last point, it is possible to say that the influence of tropical weather on storage problems, with predominance of high temperatures and humidity, has contributed for the attainment of low quality product.

Right after seeds reach physiologic maturity, storage phase is initiated, even before harvest is performed, called field storage [4]. However, for it is hygroscopic, seeds present a considerable variation of water content, due to relative humidity [5], and because of that, low water content in the seed associated with the low temperature of the storage environment and lower relative humidity, are relevant factors for viability and vigor maintenance of the seed for a long term period [6].

Storage is portrayed as an essential aspect to be taken into account within production process, for efforts applied in production phase might not be effective if seed quality is not kept, at least, up to sowing time [7]. Amongst the factors that influence conservation of viability and vigor of seeds, it is highlighted: initial physiologic quality of the seed, vigor of mother plant, climatic conditions during maturity, mechanic damages during and after harvest, action of microorganisms and insects, drying conditions, proper water content, relative humidity, storage temperature, types of packaging and storage length [8].

Pigeonpea seeds contain high quantity of protein similar to common beans (Phaseolus vulgaris) $\longrightarrow 22 \%$, being classified as amyl-protein [2], which turns out to be a roadblock for medium and long term storage, compared to seeds 
which are exclusively stacker of starch—corn, rice, wheat, etc. [9] evaluated the physiologic quality of pigeonpea seeds, and have found out that there was a decrease in vigor and viability over ten months of storage. This behavior can be attributed to, according to [10], alteration in chemical composition of the seed, once there is a partial catabolism of proteins, are examples of the changes in chemical composition during deterioration, leading to difficulties in attaining seeds with high germination capacity and vigor.

Storage will only be efficient in keeping the initial quality of the seed lot after going through stages of harvest and processing, if water content is reduced considerably during drying phase. That high water contents in the seeds increases the breathing process such as metabolism of reserves, in special proteins, besides favoring for microorganism attacks during storage, notably pathogens (fungi). The proper values for water content in the seeds for storage, ranging from 12 to $7 \%$, depending on the type of reserve stored: for amylaceous seeds it is $12 \%$, while for oil and amyl-protein seeds including pigeonpea, it is $10 \%$. For vegetable seeds, stored in an air-proof environment (cans) this content can be much more reduced, around 7\% [11]. However, for pigeonpea seeds there are no studies indicating which is the ideal water content for seed storage.

In the literature recent information regarding seed conservation for pigeonpea are rare and little conclusive, as for the study from [12], studying the germination behavior of two cultivars of pigeonpea seeds (one with hard seeds and another without) during storage in paper bags throughout six years under laboratory environment conditions, without temperature control and relative humidity, and observed that the seeds from both cultivars remained viable through three years of storage with germination over $70 \%$, with decrease in the sixth year at $10 \%$. The presence of hard seeds yielded the difference in the cultivar germination throughout storage period.

This way, it is possible to affirm that investigative works regarding pigeonpea seed storage are practically inexistent, even in the Northeast region of Brazil. Thus, it is essential the search for this information, making it feasible a better data base for technicians and producers regarding the aspects related to this fabacea, notably, those relative to appropriate procedures for seed conservation of superior physiologic quality. In addition to that, it can be said that storage is a fundamental practice for controlling the physiologic quality of the seeds, being a method which it might be possible to preserve seed viability and keep vigor in a reasonable level in the period between sowing and harvest, being the latter totally dependent on water quantity present due to storage.

This study had the aim of evaluating the physical quality of dwarf pigeonpea seeds with different water contents, submitted to storage for ten months, under weather conditions from the Central region of Goiás State, Brazil.

\section{Material and Methods}

\subsection{General Information}

The seeds of dwarf pigeonpea cv. Iapar 43, Brown-reddish color, presenting hard 
seeds, were brought and stored at UEG/UnUCET, in the lab for Drying and Storage of Vegetable Products from Agriculture Engineering course, during the period from October 2012 to August 2013. The seeds were re-moisturized, and after submitted to a drying process until they could reach desirable water content for storage.

\subsection{Experimental Design and Treatments}

The randomized delimitation was used, in factorial scheme $3 \times 7$, with four replications. Treatments were constituted by the combination of seed lots containing three water contents $(11 \%, 14 \%$ and $16 \%)$, submitted to a 10 -month storage, with evaluations each two months (0, 2, 4, 6, 8 and 10).

\subsection{Trait Measurements}

The seeds were stored in a kraft type bag under normal lab conditions, that is, with no control. Each treatment was placed in a single pack (kraft bag), containing stored seed enough for analysis for each bimester, that is, the seeds did not return to storage after being retrieved for analysis.

In the experiment setting, before packing the seeds, the water content in the seeds was determined according to the Rule of seed Analysis (RSA), by hothouse standard method, where the seeds were subjected to drying at $105^{\circ} \mathrm{C} \pm 3^{\circ} \mathrm{C}$ during 24 hours, with outcomes expressed in percentage [13]. The setting of water content was repeated in each evaluation time of the physiologic quality of the seeds in all storage conditions.

The evaluation of physiologic quality of the seeds coming from several treatments was verified by the following tests: Standard Germination Test-SGT, First Count of SGT, accelerated aging and Electric Conductivity.

The standard germination test was performed with four replications. Over three germitest sheets, moistened with three times more water than its original weight, 25 seeds per replication were placed, wrapped and packed in a germinator at $25^{\circ} \mathrm{C}$. The evaluation was carried out on the $14^{\text {th }}$ (fourteenth) da after test setting. The percentage of normal seedlings was calculated [13].

The first count test of germination was conducted alongside with SGT, considering the percentage of normal seedlings present on the $7^{\text {th }}$ (seventh) day after the beginning of the test.

For accelerated aging 100 seeds per replication was distributed over the surface of a metal net fixed inside a plastic Box-gerbox, with $40 \mathrm{ml}$ of water, 100\% relative humidity kept at $42^{\circ} \mathrm{C}$, for 48 hours in a germinator [14]. After this period, the seeds were subjected to SGT, aforementioned, to determine the percentage of normal seedlings on the $7^{\text {th }}$ (seventh) day after test setting.

The electric conductivity test was performed in a cup system recommended by [14], in which 50 seeds per replication previously weighted and placed in plastic cups, with $75 \mathrm{ml}$ of deionized water, and kept in the germinator at constant $25^{\circ} \mathrm{C}$ during 24 hours. The reading of electric conductivity was performed by a con- 
ductivity meter and the results expressed in $\mu \mathrm{S} \cdot \mathrm{cm}^{-1} \cdot \mathrm{g}^{-1}$ of seeds.

\subsection{Data Analysis}

The data was subjected to variance analysis, and the statistic differences among factors were described by means of regression analysis. The statistic calculations were performed by the statistic program SISVAR.

\section{Results}

\subsection{Variance Analysis (Average Squares) of the Test Applied to Pigeonpea Seed regarding Different Water Contents and Storage Periods}

The water content in the pigeonpea seeds was constant during the storage period, showing that the hygroscopic balance with the environment behaved in an analog way, with little variance of the studied values. This is relevant in evaluations for it supplies greater dependability on data retrieving.

By the outcome of the variance analysis, it can be verified that the interaction between water content $\times$ storage period has influenced the physiologic quality of pigeonpea seeds in all analyzed tests (Table 1).

\subsection{Germination Percentage in the Germination Test Applied to Pigeonpea Seeds regarding Water Contents and Storage Period}

The outspread of the effect of the storage period $\times$ water content made it possible to verify that germination for pigeonpea seeds, in general, increased linearly throughout storage. However, the decrease in the percentage of germination for normal seedlings was less accentuated when the seed lot presented lower water content $-11 \%$, because in the tenth month of storage the former still presented $66 \%$ of germination (Figure 1). On the other hand, seed storage with water content at $14 \%$ and $16 \%$, promoted a drastic decrease in pigeonpea seed viability, reaching percentages $52 \%$ and $38 \%$ respectively, after 10 -month storage.

Table 1. Outcome from variance analysis (average squares) of the test applied to pigeonpea seed regarding different water contents and storage periods.

\begin{tabular}{cccccc}
\hline & & \multicolumn{4}{c}{ Average squares } \\
\cline { 3 - 6 } Variance sources & G.L. & Germination & First count & $\begin{array}{c}\text { Accelerated } \\
\text { aging }\end{array}$ & $\begin{array}{c}\text { Electric } \\
\text { conductivity }\end{array}$ \\
\hline Water content (T) & 2 & $1477.87^{*}$ & $1046.27^{*}$ & $1089.30^{*}$ & $10,401.90^{*}$ \\
Storage (A) & 5 & $495.01^{*}$ & $468.35^{*}$ & $259.55^{*}$ & $3256.66^{*}$ \\
T $\times$ A & 10 & $89.66^{*}$ & $93.35^{*}$ & $66.19^{*}$ & $415.60^{\star}$ \\
Residue & 54 & 30.21 & 27.64 & 23.76 & 113.07 \\
C.V. & - & 12.99 & 13.09 & 11.36 & 11.23 \\
\hline
\end{tabular}

G.L. Degrees of liberty; ${ }^{\star}$ Significance at $5 \%$ probability by $\mathrm{F}$ test. 


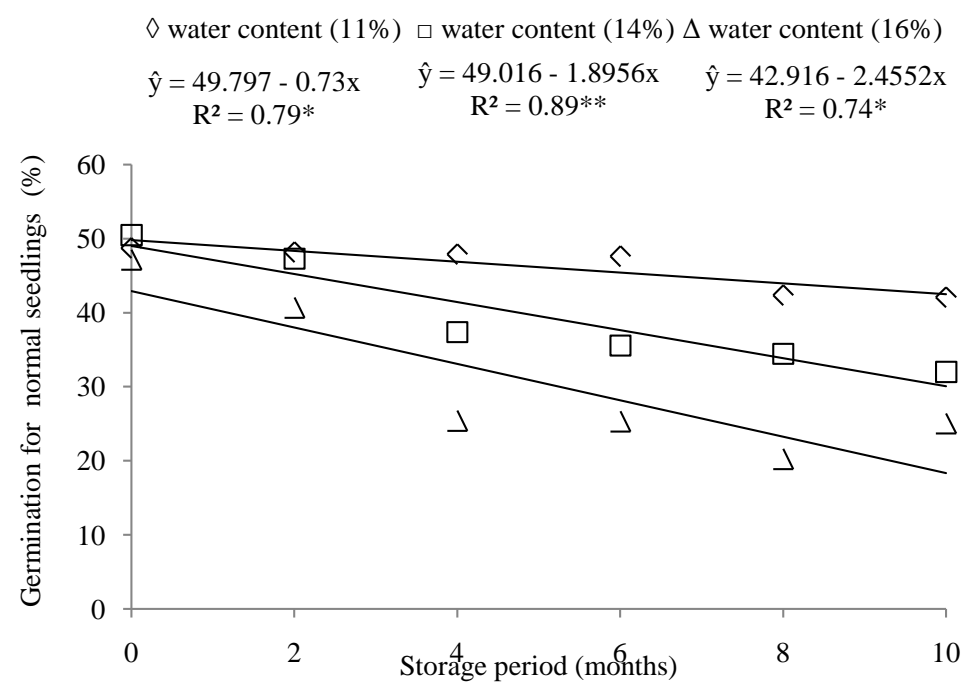

Figure 1. Germination percentage in the germination test applied to pigeonpea seeds regarding water contents and storage period.

\subsection{Germination Percentage for the First Count Test of SGT Applied to Pigeonpea Seeds regarding Water Contents during Storage}

Vigor for pigeonpea seeds retrieved in the first count test initially presented inferior values from the ones in the germination test. Similarly to germination test, it can be verified that the stored seeds with water content at $11 \%$ presented a better quality pattern, despite of linear decrease of normal seedling percentage throughout storage. Still, decrease in physiologic quality was more drastic in the pigeonpea seeds stored containing higher water contents, $14 \%$ and $16 \%$, reaching normal seedlings percentage at $30 \%$ and $21 \%$, respectively (Figure 2 ).

\subsection{Germination Percentage for Accelerated aging Test Applied to Pigeonpea Seeds concerning Water Contents and Storage Period}

The outcomes from the accelerated aging test confirm those obtained in the first count test, with higher germination values in the water contents of $11 \%$ during storage.

\subsection{Reading for Electric Conductivity Test Applied to Pigeon Pea Seeds concerning Water Contents and Storage Period}

The outcome for the electric conductivity test presented opposite behavior to other analyzed tests (Figures 1-3).

In this context, it can be verified that the lower conductivity readings were verified in the pigeonpea seed lot with water content at $11 \%$, with a less sharp increase throughout storage. But for higher water contents in the seed, $14 \%$ and $16 \%$, it can be observed sharper increase in the readings, certainly generated by higher metabolic rates of the seed associated with membrane system disruption, reaching respective values of 124 and $161 \mu \mathrm{S} \cdot \mathrm{cm}^{-1} \cdot \mathrm{g}^{-1}$, which allows for classifying pigeonpea seed lots as low quality. 


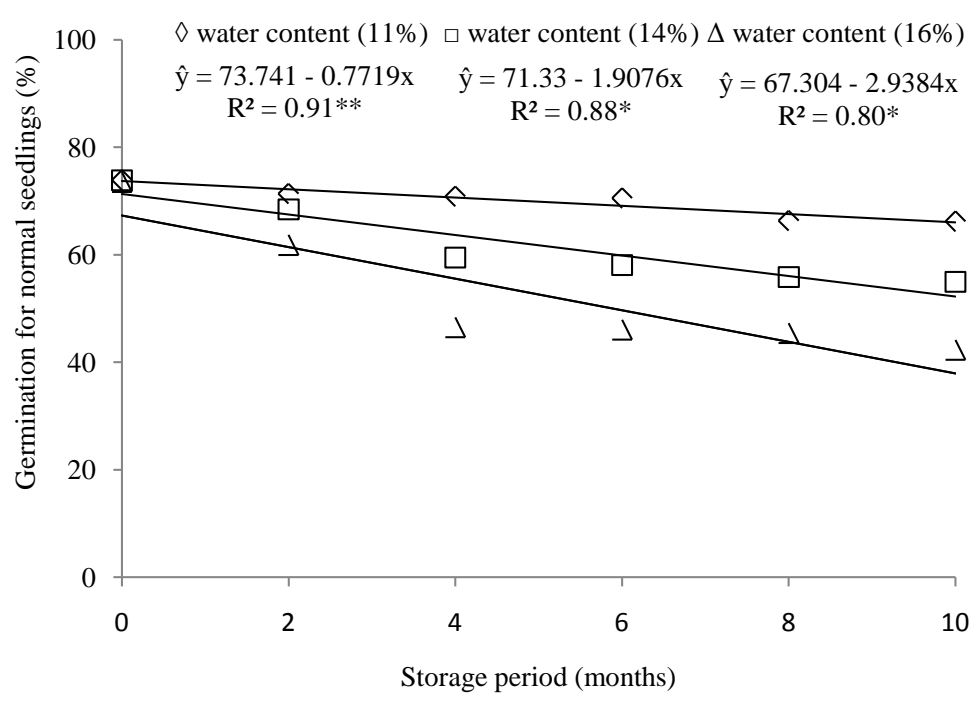

Figure 2. Germination percentage for the first count test of SGT applied to pigeonpea seeds regarding water contents during storage.

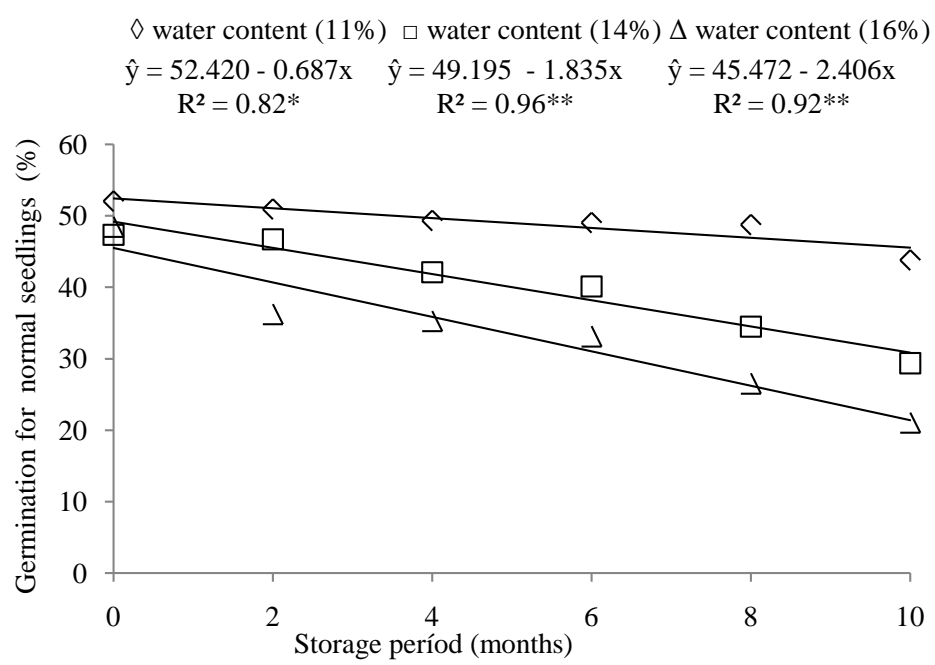

Figure 3. Germination percentage for accelerated aging test applied to pigeonpea seeds concerning water contents and storage period.

\section{Discussion}

The germination for pigeonpea (Figure 1) seeds, in general, increased linearly throughout storage, outcome that agrees with affirmations from [11], that affirm that storage only postpones the loss in seed quality, and by no means enhances its physiologic quality.

The performance of drying up to the water content of $11 \%$ certainly contributed for the decrease in metabolism indexes of the reserves, especially in the protein fraction, whose centesimal composition in the seed is at 23\% [15]. Certainly the elevated water contents of $14 \%$ and $16 \%$ contributed for the acceleration in breathing rates of the reserves, and consequently, loss in seed viability during packaging.

The Agriculture Ministry (MAPA) demands that germination rates be at $70 \%$ 
for commercialization of pigeonpea seeds in Brazil [13]. This way, it can be verified that analysis performed at zero time, that is, in the occasion that seed lots were subjected to packing in different analyzed water contents, the average germination rate $(71 \%)$ was above the referred standard. However, decrease in quality has been identified from the fourth month of storage, resulting accentuated reduction in germination patterns at the end of the experiment for the higher water contents studied.

Germination percentages at $66 \%$ as the one found in the present study in the seed lot with water content at $11 \%$, after one year of storage can be considered satisfactory for the species aforementioned. Results from [9] agree in part with the ones obtained, when they verified that germination percentage in pigeonpea seeds, up to the tenth month kept germination at $64 \%$ in a non-controlled and controlled environment.

The fact that the vigor of the pigeonpea (Figure 2) seeds initially presented values inferior to those obtained in the germination can be considered normal, once vigor rate is commonly inferior than viability, however, the ideal is that they remain closer [11]. Higher water contents in the seeds result in gradient increase of breathing rates in the reserves, according to what was observed for the water contents of $14 \%$ and $16 \%$.

The principle of realization of accelerated aging (Figure 3 ) test in the initial phase, with the use of high temperatures $\left(>40^{\circ} \mathrm{C}\right)$ combined with high humidity $(>90 \%)$, taken as stress [14], probably contributed retrieving higher percentage rates of normal seedlings than first count, which is due to a possible break in dormancy of the hard seeds within the lot regarding initial treatment.

[16] verified in genotypes with hard seeds a similar behavior to the one described concerning the presence of them during a 15-month storage under conditions with temperature at $10^{\circ} \mathrm{C}$ and humidity at $25 \%$; there were genotypes which presented decrease, but after distinct storage periods, others remained with constant percentages during the whole period and others still with increase of hard seeds, followed by decrease. For [12], the presence of hard seeds in a certain lot, although it is a characteristic of preservation of the seeds and species, it is not desirable for commercial cultivars, for it brings up inconveniences when implementing the crop and for perpetuation the populations related to them, turning them into weeds in the crop or future pasture. For pigeonpea, still it might present hard seeds [13], this percentage presents do not constitute a problem for commercial cultivars.

In relation to electric conductivity test (Figure 4) the water contents of $14 \%$ and $16 \%$ presented the highest values for this characteristic, behavior contrary to that observed in the Figures 1-3, where seeds lots with higher water content presented higher mean values for electrical conductivity. However, this behavior is justified and it is part of the function principle of the test, where the higher readings for conductivity match seed lots of inferior quality, and which is related to disruption of the membrane system, releasing higher rates of compounds (reserves) into the watery environment [14]. 


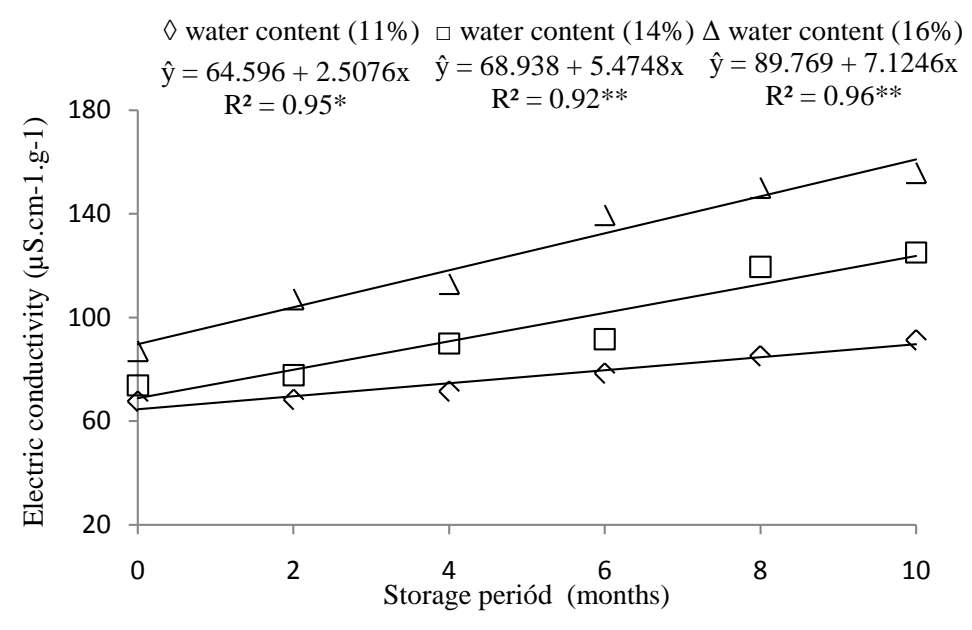

Figure 4. Reading for electric conductivity test applied to pigeonpea seeds concerning water contents and storage period.

In this context, it can be verified that the lower conductivity readings were verified in the pigeonpea seed lot with water content at $11 \%$, with a less sharp increase throughout storage. But for higher water contents in the seed, $14 \%$ and $16 \%$, it can be observed sharper increase in the readings, certainly generated by higher metabolic rates of the seed associated with membrane system disruption, reaching respective values of 124 and $161 \mu \mathrm{S} \cdot \mathrm{cm}^{-1} \cdot \mathrm{g}^{-1}$, which allows for classifying pigeonpea seed lots as low quality.

[9] analyzing the physiological quality of pigeonpea seeds during the storage and in different packages observed lower values for electrical conductivity for the kraft bag (ranging from 80 and $100 \mu \mathrm{S} \cdot \mathrm{cm}^{-1} \cdot \mathrm{g}^{-11}$ ) in relation to this research. [17] evaluating physiological quality of pigeonpea seed after application of desiccant herbicides observed lower values for electrical conductivity to zero storage time observed in this work $\left(53.2 \mu \mathrm{S} \cdot \mathrm{cm}^{-1} \cdot \mathrm{g}^{-1}\right)$.

\section{Conclusions}

Pigeonpea seeds with water content at $11 \%$ present better superior physiologic quality throughout a 10-month storage period, under uncontrolled conditions.

Packing for pigeonpea seeds with water content superior to $14 \%$ promotes a sharp decrease in physiologic quality.

\section{Acknowledgements}

To the Foundation for Support of Higher Education (CAPES) the partial funding of research. The National Council for Scientific and Technological Development $(\mathrm{CNPq})$ the receive of productivity in research grants to the tree author.

\section{References}

[1] Saxena, K.B. (2008) Genetic Improvement of Pigeon Pea: A Review. Tropical Plant Biology, 1, 159-178. https://doi.org/10.1007/s12042-008-9014-1

[2] Saxena, K.B., Kumar, R.V. and Sultana, R. (2010) Quality Nutrition through Pig- 
eonpea-A Review. Health, 2, 1335-1344.

https://doi.org/10.4236/health.2010.211199

[3] Mula, M.G. and Saxena, K.B. (2010) Lifting the Level of Awareness on pigeonpea-A Global Perspective. International Crops Research Institute for the Semi-Arid Tropics (ICRISAT), Patancheru.

[4] Ferreira, V.F., Oliveira, J.A.A., Ferreira, T.F., Reis, L.V., Andrade, V. and Costa Neto, J. (2013) Quality of Maize Seeds Harvested and Husked at High Moisture Levels. Journal Seed Science, 35, 263-273. https://doi.org/10.1590/S2317-15372013000300001

[5] Leprince, O. and Buitink, J. (2010) Desiccation Tolerance: From Genomics to the Field. Plant Science, 179, 554-564. https://doi.org/10.1016/j.plantsci.2010.02.011

[6] Suma, A., Sreenivasan, K., Singh, A.K. and Radhamani, J. (2013) Role of Relative Humidity in Processing and Storage of Seeds and Assessment of Variability in Storage Behaviour in Brassica spp. and Eruca sativa. The Scientific World Journal, 1, 1-9. https://doi.org/10.1155/2013/504141

[7] Zonta, J.B., Araujo, E.F., Araujo, R.F., Dias, L.A.S. and Ribeiro, P.H. (2014) Storage of Phisic Nut Seeds in Different Environments and Packagings. Bioscience Journal, 30, 599-608.

[8] Pandey, A.K., Palni, U.T. and Tripathi, N.N. (2012) Evaluation of Clausena pentaphylla (Roxb.) DC Oil as Fungitoxicant against Storage Mycoflora of Pigeon Pea Seeds. Journal of the Food and Agriculture, 93, 1680-1686. https://doi.org/10.1002/jsfa.5949

[9] Lisboa, C.F., Cunha, D.A., Teixeira, I.R., Devilla, I.A. and Campos, A.J. (2014) Physiological Deterioration of Pigeon Pea Seeds during Storage. African Journal of Agricultural Research, 9, 3473-3479.

[10] Copeland, L.O. and McDonald, M.B. (1999) Principles of Seed Science and Technology. Kluwer Academic Publishers, London, 409 p. https://doi.org/10.1007/978-1-4615-1783-2

[11] Marcos Filho, J. (2015) Fisiologia de sementes de plantas cultivadas. [Seed Physiology of Cultivated Plants.] Abrates, Londrina, 660 p.

[12] Nakagawa, J., Cavariani, C. and Toledo, M.Z. (2009) Germinação de sementes armazenadas de guandu. [Germination of Stored Pigeonpea Seeds.] Revista Brasileira de Sementes, 31, 43-48. https://doi.org/10.1590/S0101-31222009000400005

[13] Brasil (2009) Regras para análises de sementes. [Rules for Seed Analysis.] Ministério da Agricultura e relativa Reforma Agrária, Brasília, 398 p.

[14] Krzyzanowski, F.C., Vieira, R.D. and França Neto, J.B. (1999) Vigor de sementes: Conceitos e testes. [Seed Vigour: Concepts and Tests.] Abrates, Londrina, 218 p.

[15] Teixeira, J.P.F., Spoladore, D.S., Braga, N.R. and Bulisani, E.A. (1985) Composição química de grãos de feijao-guandu cultivar kaki. [Chemical Composition of Pigeonpea cv. kaki.] Bragantia, 44, 457-463. https://doi.org/10.1590/S0006-87051985000100043

[16] Godoy, R. and Souza, F.H.D. (2004) Dormência em sementes de guandu (Cajanus cajan (L.) Millsp). [Dormancy on Pigeonpea Seeds (Cajanus cajan (L.) Millsp).] Revista Brasileira de Zootecnia, 33, 2201-2205. https://doi.org/10.1590/S1516-35982004000900004

[17] Guimarães, R.T., Teixeira, I.R., Campos, A.J., Silva, G.C., Devilla, I.A., Silva, A.G. and Timossi, P.C. (2015) Physiological Quality of Pigeonpea Seed after Application of Desiccant Herbicides. American Journal of Plant Sciences, 6, 826-832. https://doi.org/10.4236/ajps.2015.66089 
Submit or recommend next manuscript to SCIRP and we will provide best service for you:

Accepting pre-submission inquiries through Email, Facebook, LinkedIn, Twitter, etc. A wide selection of journals (inclusive of 9 subjects, more than 200 journals)

Providing 24-hour high-quality service

User-friendly online submission system

Fair and swift peer-review system

Efficient typesetting and proofreading procedure

Display of the result of downloads and visits, as well as the number of cited articles Maximum dissemination of your research work

Submit your manuscript at: http://papersubmission.scirp.org/

Or contact ajps@scirp.org 